\title{
MODEL STUDENT LEARNING AND ESQ STKIP PANCA SAKTI BEKASI FACING INDUSTRIAL REVOLUSTION 4.0
}

\author{
Dewi Endah Fajariana \\ Economics Education Department \\ STKIP Panca Sakti Bekasi, Jawa Barat, Indonesia \\ dewiendah.stiekridatama@gmail.com
}

\begin{abstract}
The flow of globalization has no longer stopped entering Indonesian territory accompanied by increasingly sophisticated technological developments, the world is now entering the industrial revolution era 4.0. Facing these challenges, universities are required to change, including in producing quality bachelor candidates for future generations. The target of these changes is students in universities, because future job competency needs are cognitive abilities, physical abilities, content skills, process skills, social skills, system skills, complicated problem solving skills, resource management skills and technical skills. Therefore, an innovative lecture is needed so that students do not feel bored and are able to master the science and technology received at college with stable emotional intelligence. Innovative lectures are the delivery of lecture materials using learning models so that students are not bored because the majority of STKIP students, especially economic education, work. This type of research uses a qualitative descriptive approach. Research that intends to understand the phenomenon of what is experienced by research subjects students who contract subjects of microeconomic theory, the Indonesian economy and the introduction of economics A and B.
\end{abstract}

Keywords: Learning Model, ESQ, Revolution 4.0.

\section{INTRODUCTION}

The flow of globalization has been unstoppable into Indonesian territory accompanied by increasingly sophisticated technological developments, the world is now entering the era of the industrial revolution 4.0 which emphasizes the pattern of; (1) digital economy, namely economic and business activities based on digital technology, where the implementation of economic activities and business through internet and web-based markets, (2) artificial intelligence is artificial intelligence, where intelligence is created and put into a machine / computer to do work that can be done by humans, (3) big data is a collection of very large amounts of data. large and complex so that makes it difficult to handle or process if only using ordinary database management, because big data guarantees the processing of data solutions with new or existing variants to provide tangible benefits for business, (4) robotic is a set of mechanical tools that can do physical tasks, both with supervisors human control and use programs that have been defined in advance and others or known as the phenomenon of disruptive innovation, namely the phenomenon of innovation that helps create new markets, disrupt or damage existing markets and ultimately replace the previous technology (Wikipedia, 2018). According to sources (Future of Jobs Report, World Economic Forum, 2018) there are 10 (ten) relevant skills in the 4.0 industrial revolution as follows:
1) Complex problem solving
2) Critical thinking
3) Creativity
4) People management
5) Coordinating with others
6) Emotional intelligence
7) Judgment and decision making
8) Service orientation
9) Negotiation
10) Cognitive flexibility

Facing these challenges, the teaching system in higher education is demanded to change, including in producing qualified undergraduate candidates for future generations. The target of the change is students in tertiary institutions, in terms of learning and student affairs, changes in curriculum reorientation are needed to build competence in the industrial revolution 4.0 
era such as grants and technical guidance, problem-based learning and e-learning. While in the field of research and development, strengthening innovation includes the application of digital technology in managing research, harmonizing the results of research and innovation in the business or industrial world. Foreign universities that will enter Indonesia are already in line, lest it be a threat but an opportunity to change to improve the quality of education in Indonesia.

The quality of education in each educational institution will affect the quality of education nationally. The degree of quality of education is determined by the components of students, teachers / educators, curriculum, learning strategies, media, facilities and infrastructure, time and availability of funds, and the community and socio-culture. Basically, the quality levels of all components contribute and color to the overall education process. Therefore, in an effort to achieve an accountable education system, every educator should be able to create a new learning strategy so that students do not feel bored studying at the university level which is identical to the monotonous and boring learning system because they still use the old system, namely lectures. The majority lecture system is used in Indonesia, because it is fairly easy to do by a lecturer but it does not pay attention to the development of students. Today's students no longer need the full lecture system in class. But it requires a lecture system that is based on problems and its resolution by discussion using the technology they master. The use of technology in Indonesia is still relatively low, but the use of technology in the education world is currently very much needed. So like it or not, students in Indonesia have to use technology to keep it out of date.

Indonesia is the largest archipelago country in the world which has approximately 250 ethnic groups, and is classified as an Asian country with a very large population of around 262 million people. If the population is well fostered and a soul is developed to advance, learn and do entrepreneurship, it will become a reliable national asset and be able to compete in the global market. Moreover, this condition is supported by natural resources which are quite rich and diverse. These conditions cannot yet be fully used as development capital. This is proven even though the progress of development has produced a lot of educated workers, but the conditions have not been fully encouraging, due to the still large number of unemployment. Where, economic growth is at the level of $5.17 \%$ in the first semester of 2018, the highest since 2014 and the unemployment rate is at $5.13 \%$ (the lowest in two decades) and the poverty rate at $9.8 \%$ (the lowest in two decades). (Kompas, 2018)

Factually according to the version of the World Economic Forum (WEF) ranked Indonesia has always been far below Singapore's position that in 2018 it was ranked third (3) of the world or the first ASEAN. Version WEF competitiveness is the competitiveness of a country / economy, not the competitiveness of a product. Naturally high competitiveness of a country would greatly help the competitiveness of the products of the country, however, the competitiveness of a product is also determined by a number of factors, both internal as exchange rates, interest rates that affect the cost of production / investment, productivity and other -Other as well as external factors such as the structure of global markets and others. The methodology used by the WEF competitiveness index to determine a particular country in ASEAN, namely the basic requirements such as institutional, infrastructure, conditions (stability) of the macro economy and the level of education and public health. Here are the actual facts of the WEF version:

\section{Global Competitiveness Rating (Global Competitiveness Index / GCI) ASEAN Member Countries According to the version of the World Economic Forum (WEF) 2016 and 2017}

\begin{tabular}{cccccc}
\hline No. & $\begin{array}{c}\text { Member } \\
\text { states }\end{array}$ & GCI & GCI & GCI & GCI \\
& & $2014-$ & $2015-$ & $2016-$ & $2017-$ \\
& & 2016 & 2017 & 2018 \\
\hline 1. & Singapore & 2 & 2 & 2 & 3 \\
2. & Malaysia & 24 & 18 & 25 & 23
\end{tabular}




\begin{tabular}{clcccc} 
3. & $\begin{array}{l}\text { Brunei } \\
\text { Darussala }\end{array}$ & - & - & 58 & 42 \\
& m & & & \\
4. & Thailand & 37 & 32 & 34 & 32 \\
5. & Indonesia & 38 & 37 & 41 & 36 \\
6. & Filipina & 59 & 47 & 57 & 56 \\
7. & Vietnam & 70 & 56 & 60 & 55 \\
8. & Laos & 81 & 83 & 93 & 98 \\
9. & Cambodia & 88 & 90 & 89 & 94 \\
10. & Myanmar & 139 & - & - & - \\
\hline \multicolumn{5}{l}{ Sources: } & WEF 2015, 2016, 2017 and 2018
\end{tabular}

The reality as above is caused by the lack of adequate education level. Whereas humans who have extensive education or knowledge are expected to be able to manage the factors of production in order to produce goods and services that can benefit society. Because only human production factors are capable of managing resources or other factors of production. Because the need for future work competencies are cognitive abilities, physical abilities, content skills, process skills, social skills, system skills, complicated problem solving skills, resource management skills and technical skills (World Economic Forum, 2018).

The need for future work competencies must be produced by universities that produce skilled human resources including the Panca Sakti Bekasi Teaching and Education College (STKIP), which is the majority of output universities, which are prospective teachers or educators, besides that there are still many students those who think college will immediately work to get money and meet basic needs and because there are still students who think after college work and make money, which in the end they will only focus on others to fulfill basic needs and on the fulfillment of personal ego. Not working for worship or working to help others in the environment around students, countries and religions. The demands mentioned above require STKIP to produce superior human beings in the face of the 4.0 revolution so that they can compete in the 4.0 industrial revolution, therefore an innovative lecture system is needed so that students do not feel bored and are able to master science and technology received in college. An innovative lecture system is the delivery of lecture material using learning models such as cooperative learning systems or PBL instead of the old model discussion, so students do not get bored because the majority of STKIP students, especially economic education work. So sometimes they don't focus on learning.

The concept of the learning model according Trianto $(2010$, p. 51), states that the learning model is a plan or pattern that is used as a guide in learning in the classroom or instructional tutorials. The learning model refers to a learning approach that will be used, including the purposes of teaching, the stages in the learning activities, learning environment, and classroom management. The approach in the learning model centered on the teacher, in this case the teachers deliver the subject matter in a very structured format, directing the activities of the learners, and maintain focus on academic achievement with a fusion ESQ (Emotional Spiritual Quotient) students.

ESQ (Emotional Spiritual Quotient) is the character formation of human resources which aims to explore the human potential in terms of intellectual, emotional and spiritual. During this time, three elements are separate and optimally utilized to build the human resources that have morals that will have an impact on performance (Wikipedia, 2018)

Based on the description and the above problems, researchers are interested to take the title "Model of Learning and Student ESQ STKIP Panca Sakti Bekasi Facing the Industrial Revolution 4.0".

\section{METHOD}

This research uses qualitative descriptive approach. Qualitative research is the research aims to understand the phenomenon of what is experienced by the subject of the study such behavior, how the description in the form of words and language, in a specific context naturally and by using various natural methods (Moleong, 2011). Qualitative research does not use the term population, but uses "social situation" or social situation that consists of three elements: the place (place), actors (actor), and activity (activity) that interact synergistically (Sugiyono, 2013).

Moleong (2011) further explained that a qualitative approach is taken because in this 
study the target or object of study is limited to the data captured can be extracted as much as possible and that in this study there is no possible widening of the research object. Research carried out directly in the field, formulation of the problem is also found in the field, the possibility of data vary according to the data in the field, so it will find a new theory in the middle of the field. This study is based on the inductive way of thinking, then think deductively, this study considers the data is inspiring theory.

Qualitative research using qualitative methods of observation, interviews, or review documents. The qualitative method was used for several considerations. First, adjust the qualitative method is easier when faced with the reality plural. Second, this method presents the direct nature of the relationship between researcher and respondent. Third, this method is more sensitive and more able to adjust to a lot of sharpening the joint influence of these patterns of face value.

Qualitative study, researchers conducted a study on a small scale, with a special interest group, excellence, innovation, or it could be problematic. The group studied the socio-cultural unit that is natural and interact individually or group. Of these theories can be drawn the conclusion that the qualitative descriptive study using research steps of the observation of phenomena that can be explained in detail and scientific. Scientific observation is meant is the observation that starting from the smallest things / narrow to something bigger / wider or in other words, the study of the form of inductive to deductive form.

Data in qualitative research is not a number, but a narrative description, if any figure, the figure is in the relationship of a description. In the qualitative data processing no summation of data, thus leading to the generalization. In qualitative research, the type of data source in the form of humans in research in general as respondent (respondent). The position data in the form of human resources (resource) a very important role as individuals who have the information. Researchers and speakers here have the same position, and therefore a resource rather than simply responding to the requested researcher, but he might prefer the direction and taste in presenting the information he had.

The data that the author uses to compile this research are sourced from key people. The role of the key person, hereinafter referred to informants in the research is the main thing, because of the support and the information they provide, is the main capital of researchers in obtaining research data and materials. The informant is a person who is in the scope of the research, the student subjects microeconomic theory 19 people, the Indonesian economy 20 people and an introductory economics class A amounted to 10 and $B$ were 17 so total there are 66 people who used the following population sample in STKIP Panca Sakti Bekasi due to researchers, only support the course and students were asked details about all the research data that has been provided by the researchers.

The technique used is saturated sampling, which is choosing a sample with the entire population. Data collection technique used qualitative research approaches include:

\section{Interview}

Interviews are used as data collection techniques, if the researcher wants to do an introduction to determine the issues that must be examined, and also if the researcher wants to know things from the respondents in more depth and the number of respondents is small / small. Data collection techniques based on self-reports (self-report) or at least the knowledge and personal beliefs. Interview techniques used in conducting in-depth question and answer session with the respondents. Interviews were conducted with the aim to obtain information or oral establishment of the respondents, regarding the establishment-establishment. The results of the interview in the records while the interviews, eventually reconstructed transcript of the interview. 


\section{Documentation}

The documentation technique is used because in many cases documents can be used to test, interpret and even predict, written materials such as archives and documents are carried out. Besides that, there are several reasons for the use of documentation, among others: documents and recorders are stable, rich and encouraging sources, useful as evidence for an incident, has a nature, according to the context, was born and is in the context as well as easy and not difficult to obtain. Data is an important ingredient which is useful for the problems occurred. The data used is the information related to the research.

\section{Literature}

Literature study can be interpreted as a step to obtain information from previous research that must be done, regardless of whether a study uses primary data or secondary data, whether the research uses field or laboratory research or in the room. The study of literature is the data collection techniques to conduct a study review of books, literature, records, and reports that had to do with the problem is solved (Nazir, 2011).

In this study, the data analysis technique used is the Miles and Huberman model. Data analysis in qualitative research, carried out at the time of data collection takes place, and after the completion of data collection within a certain period. At the time of the interview, researchers have done an analysis of the answers interviewed. Miles and Huberman argued that the activities in qualitative data analysis were carried out interactively and continued continuously until they were finished, so that the data was already saturated. Activities in data analysis is data reduction, data display, dan conclusion drowing/verification (Sugiyono, 2016).

In analyzing data, researchers use an interactive model, whose elements include data reduction, data display, and conclutions drowing / verifiying. The flow of data analysis techniques is as follows:

\section{Data Reduction}

Data Reduction is refinement process data, both the reduction of the data that are considered less unnecessary and irrelevant, and additional data that it is still lacking. The data obtained in the field may be very large in number. Data reduction means summarizing, choose the basic things, focus on the things that are important, look for themes and patterns. Thus, the data that will be reduced to provide a clearer picture, and facilitate researchers to conduct further data collection, and look for it when necessary (Sugiyono, 2016).

\section{Data Presentation}

Displaying or presenting data will make it easier to understand what happened during the research. After that there is a need for work planning based on what has been understood. In addition to using text data presentation in the narrative, also can be a nonverbal language such as charts, graphs, charts, matrices, and tables. Presentation of data is a process of gathering information compiled by categories or groupings required. Miles and Huberman in qualitative research data presentation can be done in the form of brief descriptions, charts, relationships between categories of flowcharts and the like. He said "the most often used to present data in qualitative research is the narrative text". (Sugiyono; 2016).

\section{Conclusion Drawing}

The final step in data analysis techniques is data verification. Verification of data is done when the preliminary conclusion that dikemukan still provisional, and there will be changes if it is not accompanied by supporting evidence that strong to support the next stage of data collection. If conclusions are made at an early stage, supported by valid and consistent evidence when research returns to the field to collect data, the conclusions raised are credible or credible conclusions. (Sugiyono, 2016). 


\section{RESULT AND DISCUSSION}

Students of class subjects STKIP especially microeconomic theory, the Indonesian economy, and an introductory economics class A and B. They prefer learning model that is guided by the lecturer then lecturer gives examples of problems and their discussions to find a solution.

The concept of the learning model according Trianto $(2010$, p. 51) states that the learning model is a plan or pattern that is used as a guide in learning in the classroom or instructional tutorials. The learning model refers to a learning approach that will be used, including the purposes of teaching, the stages in the learning activities, learning environment, and classroom management.

According to Killen in the Ministry of Education (2010) directly or Direct Instruction learning refers to various techniques of expository (transfer of knowledge from teacher to students directly, for example through lectures, demonstrations, and $\mathrm{Q} \& \mathrm{~A}$ ) involving the whole class. The approach in this learning model centered on the teacher, in this case the teachers deliver the subject matter in a very structured format, directing the activities of the learners, and maintain focus on academic achievement.

Here are the results of research or student answers on the use of direct and innovative learning model:

\begin{tabular}{|c|c|c|c|c|}
\hline No. & Courses & Class & $\begin{array}{l}\text { Online } \\
\text { Learning } \\
\text { Model } \\
\end{array}$ & $\begin{array}{l}\text { Direct } \\
\text { Learning } \\
\text { Model } \\
\end{array}$ \\
\hline 1 & $\begin{array}{l}\text { Pengantar } \\
\text { ekonomi }\end{array}$ & I-A & - & 10 \\
\hline 2 & $\begin{array}{l}\text { Pengantar } \\
\text { ekonomi }\end{array}$ & I-B & 1 & 16 \\
\hline 3 & $\begin{array}{l}\text { Teori } \\
\text { ekonomi } \\
\text { mikro }\end{array}$ & III & 9 & 10 \\
\hline 4 & $\begin{array}{l}\text { Perekonomian } \\
\text { Indonesia }\end{array}$ & V & - & 20 \\
\hline \multicolumn{3}{|c|}{ Total keseluruhan } & 10 & 56 \\
\hline
\end{tabular}
STKIP, 2018

So we can conclude that many students agree and choose if the professor teaching in the classroom, because there are still many students who do not have a strong Internet network in the region or place of residence.

\section{ESQ (Emotional Spiritual Quotient)}

ESQ students in microeconomic theory classes, Indonesian economics and introductory economics classes $\mathrm{A}$ and $\mathrm{B}$ include individuals who have good character and good spiritual, as seen from the way they enter the classroom by greeting and asking permission from lecturers. In accepting courses, they listen well and give the best solution if given a case study assignment. However, he has not been able to explore and internalize the wealth of Ruhiah, Fikriyah and Jasadiah in his life. Because there are still students who have college goals there have a large income.

ESQ model of a device spiritual engineering in character development and personality based on the values of Rukun Iman, Pillars of Islam and Ihsan, which will ultimately result in superior man in sectors emotional and spiritual, which is able to explore and internalize the wealth ruhiah, fikriyah and jasadiah in life (Agustian, 2007).

In worldly life, the human body has seven negative shackles, namely negative prejudice, life principles, experiences, interests and priorities, points of view, comparison, literature (Agustian, 2007). Seven shackles can be cleaned with Zero Mind Process. Zero Mind Process is a process of purification of emotion. If Zero Mind Process has been done then the person has been freed from the shackles of prejudice, such as the principles of life that is misleading, experience affects the mind, selfish interests, a comparison-a comparison that are subjective, and free from the influences of the shackles of literature that is misleading (Agustian , 2007). After Zero Mind Process is done, then the human body into a net of seven shackles of prejudice. To fortify it, six principles of life are needed to form a life commitment.

Here are the results of research or student answers on ESQ:

\begin{tabular}{llllll}
\hline Class & $\begin{array}{l}\text { Negati } \\
\text { ve } \\
\text { Prejud } \\
\text { ice }\end{array}$ & $\begin{array}{l}\text { Princi } \\
\text { ple Of } \\
\text { Live }\end{array}$ & $\begin{array}{l}\text { Experi } \\
\text { ence }\end{array}$ & $\begin{array}{l}\text { Interests } \\
\text { and } \\
\text { Priorities }\end{array}$ & $\begin{array}{l}\text { Point of } \\
\text { View }\end{array}$ \\
\hline I-A & & & & 10 &
\end{tabular}




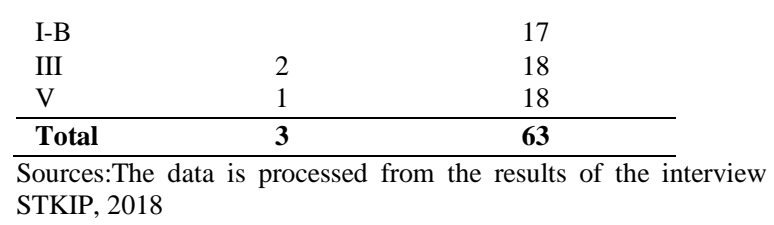

As for the comparison and the literature they do not know who would want such, if a teacher does not give examples of public figures who holds a high ESQ. So we can conclude that college students just to the interests and priorities through life to meet the individual needs of each instead of the needs of others.

\section{Industrial Revolution 4.0}

The negative impact caused by this industrial revolution is mass production of all needs including items designed by craftsmen or artists, resulting in reduced handcraft products such as ceramics, furniture, carpets and other items (Brown \& Farrelly; 2012). This happens because many craftsmen such products that have switched to cheaper mass production and produced. So that the value of the product also decreased, which was previously included in the category of luxury products turned into medium products because the amount is no longer limited.

The era of the industrial revolution 4.0 which emphasizes according to sources (Future of Jobs Report, World Economic Forum, 2018) there are 10 (ten) relevant skills in the industrial revolution 4.0 as follows:

\section{Complex problem solving}

Where unstructured problem situations or difficult to be defined and measured.

\section{Critical thinking}

Critical thinking is needed to solve complex problems as above.

\section{Creativity}

It can also be called creativity, where students need to have a mental process that will involve the emergence of new ideas to solve existing problems.

\section{People management}

Is the art of management or the art of leadership in understanding the character of the people around or within the organization to work together to solve a problem so that organizational goals can be achieved.

\section{Coordinating with others}

It is a management function to carry out various activities to avoid chaos by connecting and uniting and aligning the work of other employees or members of an organization with the leadership so that organizational goals are achieved.

\section{Emotional intelligence}

The ability of a person to receive, assess, manage and control the emotions himself and others in the vicinity when facing a complex problem.

\section{Judgement and decision making}

A decision in which the results of problem solving that must be faced firmly. That is a problem has found a solution for them, shall be resolved by an agreement that has been decided by all the organizations.

\section{Service orientation}

Customer service orientation, where the desire to help or serve others to meet their needs is greater than the benefit for themselves or for the interests of their group.

\section{Negotiation}

Is a form of social interaction when the parties involved in trying to resolve mutually different purposes and contrary to reach an agreement in solving a complex problem.

\section{Cognitive flexibility}

The ability to solve problems with different alternatives.

\section{CONCLUSION}

Competency requirements of future employment should be generated by the universities who scored skilled human resources, including the College of Teacher Training and Education (STKIP) Panca Sakti Bekasi which constitute the majority of its 
output colleges are prospective teachers or educators. The demands of the aforesaid which requires STKIP to produce human beings who excel in the face of the revolution 4.0 so it can compete in the industrial revolution 4.0, therefore we need a system of lectures innovative so that students do not get bored and be able to master science and technology received in college with stable emotional intelligence. However, it has not been able to explore and internalize ruhiah wealth, and jasadiah fikriyah in his life has not been entirety.

\section{REFERENCES}

Agus, S. (2013). Cooperative Learning Teori dan Aplikasi PAIKEM. Yogyakarta: Pustaka Pelajar.

Agustian, A.G. (2007). Rahasia Sukses Membangun Kecerdasan Emosi dan Spiritual. Cetakan ke-33. Jakarta: Arga.

Brown, R. and Farrelly, L. (2012). Materials and interior Design. London: Lawrence King.

Depdiknas. (2007). Peraturan Menteri Pendidikan Nasional RI Nomor 41 Tahun 2007 Tentang Standar Proses untuk Satuan Pendidikan

Direktorat Pembinaan Pendidikan dan Pelatihan. (2010). Model-Model Pembelajaran. Jakarta: Depdiknas.

Djamarah, S. B. (2008). Strategi belajar Mengajar. Bandung: Rineka Cipta.

Djatmiko, B. (2018). Perubahan SDM pendidikan tinggi era revolusi industri 4.0. Materi Seminar Nasional di Universitas Gunadarma. Bekasi.

Ginanjar, A. (2018). Vuca Era revolusi industry 4.0. Materi Seminar Nasional di Universitas Gunadarma. Bekasi.

Istarani. (2011). 58 Pembelajaran Inovatif (Refrensi Guru dalam Menentukan Model Pembelajaran). Medan: Media Persada.

Johson, I. (2013). Cooperative Learning. Bandung: Alfabeta. Kompas. 2018.

Moleong, L. (2011). Metodologi Penelitian
Kualitatif. PT. Remaja Rosdakarya, Bandung.

Nazir, M. (2011). Metode Penelitian. Jakarta: Ghalia Indonesia.

Sagala, S. (2010). Konsep dan Makna Pembelajaran. Bandung: Alfabeta.

Sugiyono, (2016). Memahami Penelitian Kualitatif. Bandung: Alfabeta.

Trianto. (2007). Model - Model Pembelajaran Inovatif Berorientasi Konstruktivistik. Jakarta: Prestasi Pustaka. World Economic Forum. 